UDC 615.276:547.789:542.91

\title{
Antimicrobial and cytotoxic activities of thiazolo[4,5-b]pyridine derivatives
}

\author{
A. V. Lozynskyi ${ }^{1}$, H. O. Derkach ${ }^{2}$, V. V. Zasidko², Y. T. Konechnyi ${ }^{1}$, N. S. Finiuk ${ }^{3}$, \\ Y. T. Len ${ }^{4}$, R. V. Kutsyk ${ }^{2}$, M. S. Regeda ${ }^{1}$, R. B. Lesyk ${ }^{1,5}$ \\ ${ }^{1}$ Danylo Halytsky Lviv National Medical University \\ 69, Pekarska Str., Lviv, Ukraine, 79010 \\ 2 Ivano-Frankivsk National Medical University \\ 2, Halytska Str., Ivano-Frankivsk, Ukraine, 76018 \\ ${ }^{3}$ Institute of Cell Biology, NAS of Ukraine \\ 14/16, Drahomanov Str., Lviv, Ukraine, 79005 \\ ${ }^{4}$ Lviv Scientific research forensic center of the Ministry of Internal Affairs of Ukraine \\ 24, Konyushynna Str., Lviv, Ukraine, 79040 \\ ${ }^{5}$ University of Information Technology and Management in Rzeszow \\ 2, Sucharskiego Str., Rzeszow, Poland, 35-225 \\ dr_r_lesyk@org.lviv.net,roman.lesyk@gmail.com
}

\begin{abstract}
Aim. The screening of antimicrobial and cytotoxic activities of thiazolo[4,5- $b]$ pyridine derivatives was accomplished. Methods. The antibacterial and antifungal activities of synthesized thiazolopyridines were evaluated in vitro with the agar diffusion and broth microdilution methods using clinical and reference strains of Gram-positive, Gram-negative bacteria and yeasts. The structure-antibacterial/antifungal activity relationships of the screened compounds were established. The target compounds were screened for their cytotoxicity effects on $\mathrm{HaCaT}$ and HEK293 cells using MTT assay. Results. The highest antimicrobial activity was observed for compound V 2-oxo-7-thiophen-2-yl-2,3-dihydrothiazolo[4,5-b]pyridine-5-carboxylic acid with minimal inhibitory concentration (MIC) $12.5 \mu \mathrm{g} / \mathrm{mL}$ against Candida albicans. At the same time, the synthesized compounds were explored in the interaction with amoxicillin against multidrug resistant clinical isolates of $\mathrm{ES} \mathrm{L}^{+}$Klebsiella pneumonie and Staphylococcus haemolyticus (MRSH). The best synergistic activity with amoxicillin was exhibited by compound VI. HaCaT human keratinocytes and HEK293 human embryonic kidney cells demonstrated resistance to the thiazolopyridine derivatives treatment and did not reach the $\mathrm{IC}_{50}$ value up to $100 \mu \mathrm{M}$. Conclusions. The tested thiazolopyridines constitute an interesting background for further development of new chemotherapeutic agents.
\end{abstract}

Ke y w or d s: heterocyclic compounds, thiazolidinones, thiazolo[4,5- $b]$ pyridines, antimicrobial activity, antiproliferative activity

(C) 2021 A. V. Lozynskyi et al:; Published by the Institute of Molecular Biology and Genetics, NAS of Ukraine on behalf of Biopolymers and Cell. This is an Open Access article distributed under the terms of the Creative Commons Attribution License (http://creativecommons.org/licenses/by/4.0/), which permits unrestricted reuse, distribution, and reproduction in any medium, provided the original work is properly cited 


\section{Introduction}

A wide range of infectious diseases caused by different pathogens is a main focus of the searching for new highly active and low-toxic antimicrobials in modern drug discovery. A special issue in this contest is occupied by heterocyclic compounds, due to their unique ability to mimic the structure of prokaryotic cell metabolites and to bind reversibly to diverse biotargets $[1,2]$. Thus, considerable interest among antimicrobial drug-design strategies has been paid to thiazole derivatives and their structure-related analogues [3].
Noteworthy, the thiazole/thiazolidinone skeleton underlies the structure of wide antimicrobial drugs, namely, penicillins, monobactam antibiotics and sulfadrugs. Additionally, thiazolidinones have been identified as the multiinhibitors of bacterial lactamase [4], UDPgalactopyranose mutase (UGM) [5], Sortase A (SrtA) [6], Protein mannosyl transferase 1 [5], Peptide deformylase [7], UDP-N-acetylmuramate/L-alanine ligase (MurC) [8] and MurD ligase [9]. However, the mentioned heterocycles possess wide spectra of other biological

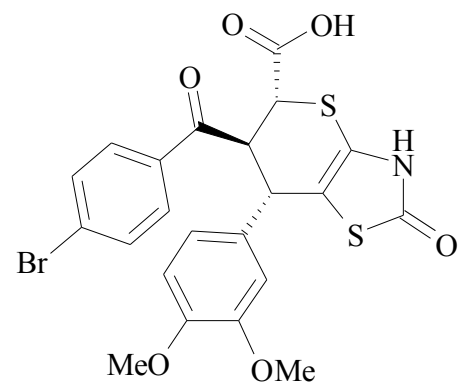

C. albicans $(\mathrm{MIC}=3.13 \mathrm{mg} / \mathrm{mL}$ )

A. Lozynskyi et al., 2017 [16]

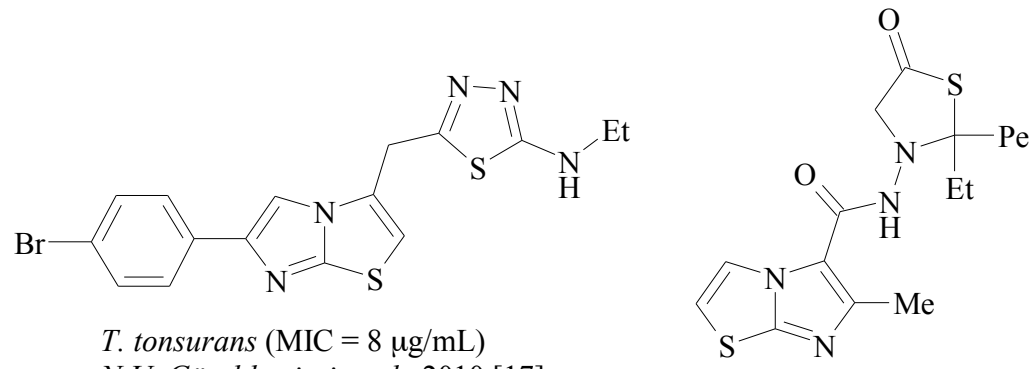

N.U. Güzeldemirci et al., 2010 [17]
S. epidermidis $(\mathrm{MIC}=19.5 \mu \mathrm{g} / \mathrm{mL}$ )

F. Ur et al., 2004 [18]
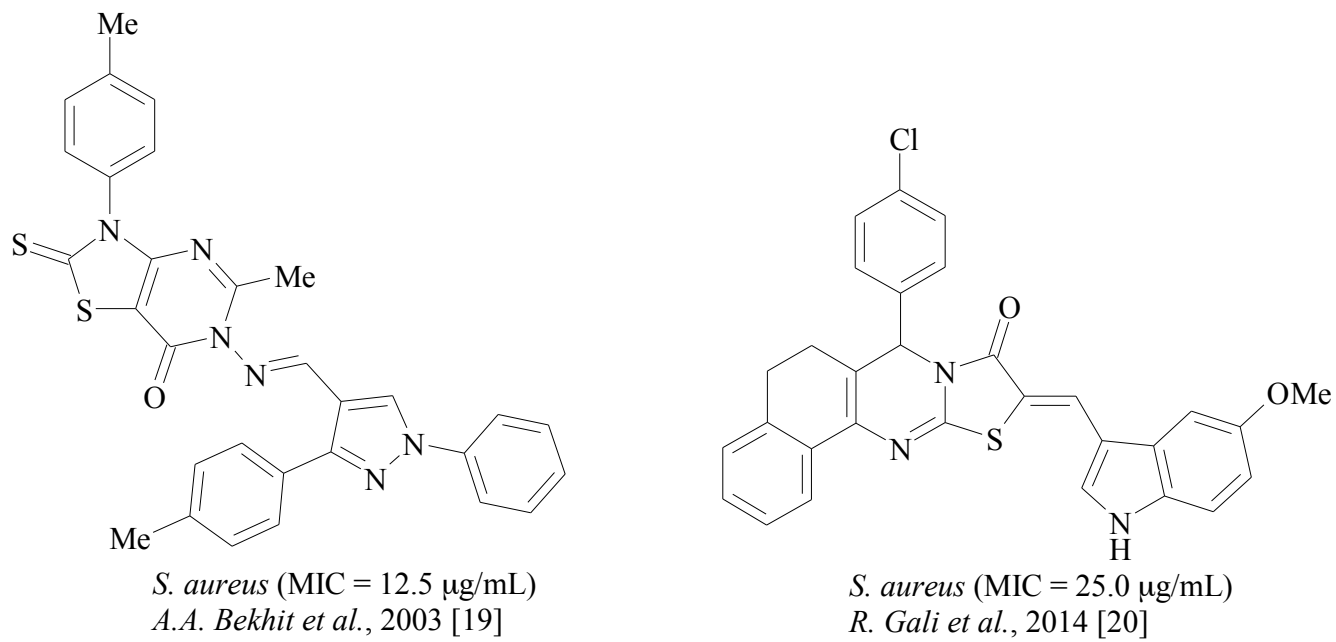

Fig. 1. Structures of fused thiazole/thiazolidinones with antimicrobial activity. 
activities, especially anticancer $[10,11]$, antitripanosomal $[12,13]$, anti-inflammatory $[14$, 15]. Interestingly, the significant antimicrobial activity was also observed for fused thiazoles, especially thiopyrano[2,3- $d]$ thiazoles [16], imidazo[2,1-b]thiazoles [17], azo[2,1-b] thiazoles [18], thiazolo[4,5- $d$ ]pyrimidines [19] and benzo $[h]$ thiazolo[2,3- $b]$ quinazolinones [20] (Figure 1). As a part of our research in the field of biologically active fused thiazoles, herein we report the antimicrobial and antiproliferative properties of some thiazolo[4,5-b] pyridine derivatives. Moreover, the pharmacological potential of thiazolopyridines has been associated with their affinity to various biotargets, especially the EGFR/ErbB family of protein-tyrosine kinases [21], histamine $\mathrm{H}_{3}$ receptors [22], G-protein coupled receptors (mGluR 5) [23], fibrillar amyloid- $\beta$ peptide (A $\beta$ ) [24], liver-selective glucokinase (GK) [25], 3',5'-cyclic adenosine monophosphate phosphodiesterase (PDE) III [26] etc. Noteworthy, we have previously established a significant antitumor activity of this class of compounds [27]. To take into account the above facts, it is promising to evaluate the biological activity of the mentioned compounds as realization of the polypharmacological strategy in the design of prospective drug-like molecules among the condensed 4-thiazolidinone derivatives.

\section{Materials and Methods}

\section{Chemistry}

The antimicrobial activity of three subtypes of thiazolopyridines, namely 5,7-diaryl-3Hthiazolo[4,5-b]pyridin-2-ones (compounds I-II), 2-oxo-7-aryl-2,3-dihydrothiazolo[4,5-b] pyridine-5-carboxylic acids (compounds IIIVI) and their amides (VII), was evaluated (Figure 2). A series of 5,7-diaryl-3Hthiazolo[4,5-b]pyridin-2-ones (I-II), 2-oxo7-aryl-2,3-dihydrothiazolo[4,5- $b]$ pyridine5 -carboxylic acids (III-VI) were obtained via [3+3]-cyclization of 4-amino-5 $H$-thiazol-2-one and chalcones or arylidene pyruvic acids (APAs) [28]. The target 7-(4-chlorophenyl)-2oxo-2,3-dihydrothiazolo[4,5- $b]$ pyridine-5-carboxylic acid (4-chlorophenyl)amide (VII) was synthesized from appropriate 2-oxo-7-phenyl-2,3-dihydrothiazolo[4,5-b]pyridine-5-carboxylic acid, which was transformed into acid chlorides and used in the acylation reaction of respective amine according to the protocol described previously [27].

\section{Antimicrobial activity}

The antimicrobial activity of the synthesized thiazolopyridines was estimated with the agar diffusion method [29]. Nutrient agar $(0.5 \%$ peptone, $0.3 \%$ beef extract, $1.5 \%$ agar, $0.5 \%$ sodium chloride, distilled water, $\mathrm{pH} \sim 6.8$ ) was used as a nutrient medium for in vitro antibacterial activity. In vitro antifungal activity was determined by using Sabouraud Agar plates. The test cultures suspensions (in concentration $1 \times 10^{7} \mathrm{CFU} / \mathrm{ml}$ ), standardized previously by the optical standard of turbidity, were uniformly sown in Petri dishes with the nutrient agar. Aliquot part $(20 \mu \mathrm{L})$ of $0.1 \%$ tested thiazolopyridine derivatives (concentration $1000 \mu \mathrm{g} / \mathrm{ml}$ ) in ethanol/dimethyl sulfoxide/ water $(2: 1: 1)$ was placed into wells (diameter of $4.0 \pm 0.1 \mathrm{~mm}$ ) in agar in Petri plates with test microorganisms. Antibacterial and antifungal activities were estimated by measuring the diameter of inhibition zone of microbial 
growth. The plates were incubated for $24 \mathrm{~h}$ at $37{ }^{\circ} \mathrm{C}$ for bacteria and for $24 \mathrm{~h}$ at $25^{\circ} \mathrm{C}$ for fungi. The inhibition zone appeared after $24 \mathrm{~h}$ was measured in mm around the well in each plate. The digital images of culture growth on dishes were obtained and processed with a computer program UTHSCSA ImageTool 2.0 (UT Health San Antonio, (C) 1995-1996) for calculation of diameters of the growth inhibition zone. Each experiment was performed by three independent researchers. The results were expressed as the means \pm S.D. The experiments were carried out on the microorganism strains, which were isolated from the ambulatory patients. The following isolated clinical strains of conditionally pathogenic bacteria were used: methicillin-sensitive Staphylococcus aureus (MSSA); methicillin-resistant Staphylococcus aureus (MRSA); methicillinresistant Staphylococcus haemolyticus (MRSH) (extended spectrum $\beta$-lactamase (ES $\beta \mathrm{L}$ ) pro- ducing); Gram-negative bacteria Escherichia coli; yeasts Candida albicans. All clinical strains were multidrug resistant (MDR) [30] and Candida albicans were resistant to fluconazole and clotrimazole. All compounds were also tested against the reference strains of Staphylococcus aureus (ATCC 25923 (F-49)), Escherichia coli (ATCC 25922), Bacillus subtilis (ATCC 6633), Klebsiella pneumoniae (ATCC 700603) and Candida albicans (ATCC 885-653) from the culture museum. Testcultures were identified using chemical microtests "STAPHYtest 16" and "ENTEROtest 24" (Erba Lachema, Czech Republic). Fungi cultures were identified on the basis of 40 biochemical tests using the VITEK 2 system with the VITEK ${ }^{\circledR} 2$ YST ID card (bioMérieux Corporate, France).

The sensitivity of strains to antibiotics was determined by disc-diffusion method and serial dilutions in agar. The MICs of the com-
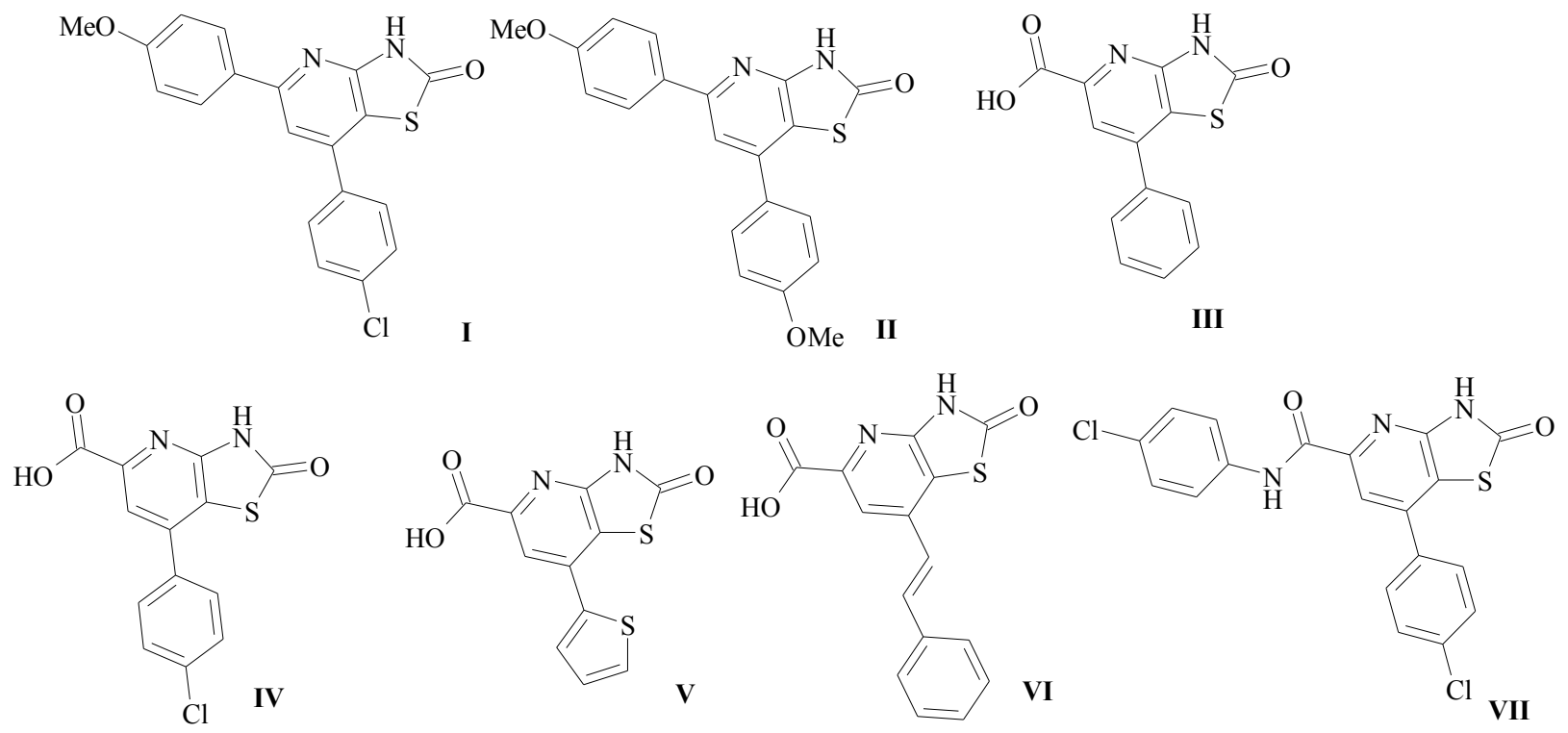

Fig. 2. Structures of tested thiazolo[4,5-b]pyridine derivatives I-VII. 
pounds were determined using the microdilution methods for antimicrobial susceptibility $[31,32]$. Microorganism suspensions were inoculated to the corresponding wells and incubated at $36{ }^{\circ} \mathrm{C}$ for $18 \mathrm{~h}$ for bacteria and at $25^{\circ} \mathrm{C}$ for $24 \mathrm{~h}$ for fungi. The presence of the microorganism growth in the bouillon (bouillon turbidity) suggested that the concentration of the compound was insufficient to suppress its viability. The first lowest concentration of the tested compounds (from a series of dilutions), where the bacterial growth was not visually determined, was the minimum inhibitory concentration (MIC). The estimation of synergy with amoxicillin for synthesized compounds has been performed by comparison of amoxicillin MICs in the presence of compounds in subinhibitory concentrations [33]. The following bacterial strains with the resistance to $\beta$-lactam antibiotics were used: Es $\beta \mathrm{L}$ (extended spectrum $\beta$-lactamase)-producing Klebsiella pneumonie ATCC 700603; methicillin-resistant Staphylococcus haemolyticus (MRSH) with double mechanisms of $\beta$-lactam resistance included both atypical penicillinbinding protein $\mathrm{PBP} 2 *$ and $\beta$-lactamase activities. The production of the atypical penicillin-binding protein $\mathrm{PBP} 2 *$ was proved by the latex agglutination reaction (Slidex ${ }^{\circledR}$ MRSA Detection, bioMérieux Corporate, France). The results have been refined by variation statistics methods.

\section{Antiproliferative activity}

The HaCaT human keratinocites and HEK293 human embryonic kidney cells were obtained from Cell Collection of R.E. Kavetsky Institute of Experimental Pathology, Oncology and Radiobiology (Kyiv, Ukraine). The cells were cultured in Dulbecco's-modified Eagle medium (DMEM, Biowest, Nuaille, France) containing $10 \%$ fetal bovine serum (Biowest, Nuaille, France) under standard conditions $\left(37{ }^{\circ} \mathrm{C}, 5 \% \mathrm{CO}_{2}, 95 \%\right.$ humidity). The stock solution of studied compounds was prepared in DMSO and diluted with the culture medium to obtain a concentration range from 0.29 to $41.63 \mu \mathrm{g} / \mathrm{mL}$. Cell viability was assessed after $72 \mathrm{~h}$ cultivation in the medium containing the studied compounds with 3-(4,5-dimethylthiazol-2-yl)-2,5-diphenyltetrazolium bromide (MTT) assay kit (EZ4U, Biomedica, Vienna, Austria) according to the manufacturer's protocol. The optical density was measured with the Absorbance Reader BioTek ELx800 (BioTek Instruments, Inc., USA) at $490 \mathrm{~nm}$ with $630 \mathrm{~nm}$ as a reference wavelength. The percentage of the viability inhibition was calculated in comparison with the untreated control cells. The $\mathrm{IC}_{50}$ values (inhibition concentrations) are the compounds concentrations that inhibit the cell viability by $50 \%$, and were calculated by GraphPad Prism 6 software (San Diego, CA, USA) using nonlinear regression. Statistical analyses were performed using twoway ANOVA test with Dunnett's multiple comparisons test. $\mathrm{P}<0.05$ was considered as statistically significant.

\section{Results and Discussion}

Antimicrobial activity of the synthesized thiazolopyridines in vitro was evaluated with the agar diffusion method. The screening was carried out against reference and clinical strains of Gram-positive and Gram-negative bacteria and yeasts: Staphylococcus aureus, Bacillus subtilis, Escherichia coli and Candida albicans. Amoxicillin for bacteria and Amphotericin-B 
Table 1. Antimicrobial activity of thiazolopyridine derivatives.

\begin{tabular}{|c|c|c|c|c|c|c|c|c|c|}
\hline \multirow{3}{*}{ Compound } & \multicolumn{9}{|c|}{ Zone of growth inhibition, $\mathrm{mm}^{*}$} \\
\hline & \multirow{2}{*}{$\begin{array}{c}\text { S. aureus } \\
\text { (ATCC } \\
25923 \\
(\text { F-49)) }\end{array}$} & \multirow[b]{2}{*}{$\begin{array}{c}\text { S. aureus } \\
\text { MSSA }^{\#}\end{array}$} & \multirow[b]{2}{*}{$\begin{array}{l}\text { S. aureus } \\
\text { MRSA }^{\#}\end{array}$} & \multirow{2}{*}{$\begin{array}{c}E . \text { coli } \\
\text { (ATCC } \\
\text { 25922) }\end{array}$} & \multirow[b]{2}{*}{ E. coli $^{\#}$} & \multirow{2}{*}{$\begin{array}{c}\text { B. subtilis } \\
\text { (ATCC } \\
\text { 6633) }\end{array}$} & \multirow{2}{*}{$\begin{array}{c}\text { C. albicans } \\
\text { (ATCC 885- } \\
653)\end{array}$} & \multicolumn{2}{|c|}{ C. albicans ${ }^{\#}$} \\
\hline & & & & & & & & Fungistatic & Fungicidal \\
\hline I & $4.15 \pm 0.08$ & $4.65 \pm 0.08$ & $7.03 \pm 0.64$ & 0 & 0 & 0 & $5.43 \pm 0.21$ & $5.91 \pm 0.22$ & $5.58 \pm 0,14$ \\
\hline II & $5.01 \pm 0.35$ & $4.78 \pm 0.45$ & $4.95 \pm 0.46$ & 0 & 0 & 0 & 0 & 0 & 0 \\
\hline III & $3.71 \pm 0.21$ & $4.76 \pm 0.29$ & $4.47 \pm 0.41$ & 0 & 0 & $6.74 \pm 0.45$ & $5.12 \pm 0.22$ & $6.21 \pm 0.36$ & 0 \\
\hline IV & $5.71 \pm 0.22$ & $4.75 \pm 0.29$ & 0 & $4.21 \pm 0.29$ & $4.21 \pm 0.29$ & $5.06 \pm 0.32$ & $4.36 \pm 0.14$ & $5.66 \pm 0.34$ & $4.30 \pm 0.42$ \\
\hline $\mathrm{V}$ & $5.88 \pm 0.81$ & $6.28 \pm 0.80$ & $4.59 \pm 0.38$ & $4.22 \pm 0.31$ & $4.22 \pm 0.31$ & $5.14 \pm 0.36$ & $8.47 \pm 0,42$ & $9.42 \pm 0,45$ & $8.11 \pm 0.24$ \\
\hline VI & $4.35 \pm 0.22$ & $4.20 \pm 0.27$ & $6.18 \pm 0.83$ & $4.74 \pm 0.29$ & $4.74 \pm 0.29$ & 0 & $6.19 \pm 0.40$ & $6.39 \pm 0.50$ & $5.21 \pm 0.76$ \\
\hline VII & $6.71 \pm 0.43$ & $7.67 \pm 0.47$ & $8.16 \pm 0.65$ & $5.04 \pm 0.28$ & $5.04 \pm 0.28$ & 0 & $6.16 \pm 0.33$ & $5.16 \pm 0.39$ & $4.25 \pm 0.33$ \\
\hline Amoxicillin & $12.78 \pm 0.41$ & $6.37 \pm 0.45$ & $5.60 \pm 0.41$ & $10.05 \pm 0.36$ & $8.20 \pm 0.35$ & $7.97 \pm 0.42$ & - & - & - \\
\hline Amphotericin-B & - & - & - & - & - & - & $11.00 \pm 0.51$ & $9.00 \pm 0.65$ & - \\
\hline
\end{tabular}

\# clinical isolates

${ }^{*}$ Data are given as mean $\pm \mathrm{SD}$.

for fungi are taken as standard drugs. The screened compounds showed different mean zone of inhibition in the range of 00-9.42 $\mathrm{mm}$ against tested microorganisms (Table 1 ). The obtained results reveal that some of thiazolopyridine derivatives possess a moderate activity towards the tested microorganisms in the dose of $20 \mu \mathrm{g}$ per well. Thus, antimicrobial activity assay allowed the identification of 2-oxo-7-thiophen-2-yl-2,3-dihydrothiazolo[4,5-b]pyridine-5-carboxylic acid $\mathbf{V}$ and 7-(4-chlorophenyl)-2-oxo-2,3-dihydrothiazolo[4,5-b]pyridine-5-carboxylic acid (4-chlorophenyl)amide VII with good growth inhibition against some tested microorganisms. The compound $\mathbf{V}$ shows the highest activity against clinical strain Candida albicans compared to standard drug Amphotericin-B. The compound VII displays a moderate antibacterial activity against $S$. aureus methicillin-sensitive (MSSA) and methicillin-resistant (MRSA) strains. MICs for compounds I-VII against several microorganisms were calculated using the broth microdilution method (Table 2). The tested compounds exhibited the inhibitory activity against MSSA and MRSA Staphylococcus aureus, Escherichia coli and Candida albicans with MIC 12.5->50 $\mu \mathrm{g} / \mathrm{mL}$. Compound V showed a moderate activity towards Candida albicans with MIC $12.5 \mu \mathrm{g} / \mathrm{mL}$. Compound VII exhibited at the same dilution inhibitory activity with MIC against MSSA and MRSA Staphylococcus aureus with MIC $50 \mu \mathrm{g} / \mathrm{mL}$.

The derivatives I-VII were studied in the interaction with amoxicillin against multidrug

Table 2. Minimum inhibitory concentration of tested compounds, $\mu \mathrm{g} / \mathrm{mL}$.

\begin{tabular}{l|c|c|c|c}
\hline Compound & $\begin{array}{c}\text { S. aureus } \\
\text { MSSA }\end{array}$ & $\begin{array}{c}\text { S. aureus } \\
\text { MRSA }\end{array}$ & E. coli & $\begin{array}{c}\boldsymbol{C} \text {. } \\
\text { albicans }\end{array}$ \\
\hline I & $>50$ & $>50$ & $>50$ & $>50$ \\
\hline II & $>50$ & $>50$ & $>50$ & $>50$ \\
\hline III & $>50$ & $>50$ & $>50$ & $>50$ \\
\hline IV & $>50$ & $>50$ & $>50$ & $>50$ \\
\hline V & $>50$ & $>50$ & $>50$ & 12.5 \\
\hline VI & $>50$ & $>50$ & $>50$ & $>50$ \\
\hline VII & 50 & 50 & $>50$ & $>50$ \\
\hline
\end{tabular}


resistant clinical isolates of $\mathrm{ES} \beta \mathrm{L}+K$. pneumonie and MRSH (Tables 3-5). According to the preliminary results of interaction screening, the thiazolopyridine derivative with a styrene fragment in the molecule VI displays the promising synergistic activity with amoxicillin against $\mathrm{ES} \beta \mathrm{L}+K$. pneumonie and $\mathrm{MRSH}$ strains. Interestingly, in numerous literature reports, the styrene fragment combined with various heterocyclic systems exhibits a significant synergistic effect with beta-lactam antibiotics [34]. Especially it can be observed for the quinoline/quinaxoline-styrene hybrid molecules structurally related to thiazolopyridines [34, 35].

The SAR analysis showed that the antibacterial effect of compounds I-VII did not depend on the substituents at $\mathrm{C} 5$ and $\mathrm{C} 7$ of thiazolopyridine core. However, the thiazolo[4,5- $b]$ pyridine-5-carboxylic acid $\mathbf{V}$ with thienyl substituent was the most active and demonstrated a good effect against Candida albicans with MIC $12.5 \mu \mathrm{g} / \mathrm{mL}$. Compound $\mathbf{V}$ possessed also a slight activity on renal cancer A498 cell line $(\mathrm{GP}=73.76 \%)$ as described previously [28]
The antimicrobial activity of thiophene-based derivatives has already been observed in the previous systematic studies, especially for condensed benzothiophene [36], thieno[2,3-d] pyrimidine [37] and thieno[3,2-c]pyrazole derivatives [38]. Additionally, the experimental study revealed that the presence of an amide fragment in thiazolopyridine core of the compound VII is also favorable for antimicrobial potency. The data concerning a critical impact of electron withdrawing groups in amide fragment are also presented in our previous paper about thiazolopyridine-5-carboxylic acid amides as possible anticancer agents [27]. On the other hand, the compounds with phenyl, 4-chlorophenyl, 4-methoxyphenyl, styryl and carboxylic substituents at $\mathrm{C} 5$ and $\mathrm{C} 7$ on thiazolo[4,5- $b]$ pyridine core were insufficient to show enhanced activity and didn't correlate with other types of activity typical for these compounds [27, 28].

Next, we used the MTT assay to investigate cytotoxicity of the thiazolopyridine derivatives towards the pseudo-normal cell line (HaCaT human keratinocytes and HEK293 human em-

Table 3. The synergistic interaction of thiazolopyridine derivatives with amoxicillin against $\mathbf{E S}_{\mathbf{S}} \mathbf{L}^{+}$ Klebsiella pneumonie ATCC 700603, zone of growth inhibition (mm), $\mathbf{M} \pm \mathbf{S}(\sigma), \mathrm{MIC}$ amoxicillin $250 \mu \mathrm{g} / \mathrm{mL}$.

\begin{tabular}{l|c|c|c|c|c}
\hline \multirow{2}{*}{ Compounds } & $\begin{array}{c}\text { Control (medium } \\
\text { without amoxicillin) }\end{array}$ & \multicolumn{4}{|c}{ Media with amoxicillin } \\
\cline { 3 - 6 } & $2.86 \pm 0.21$ & $2.75 \pm 0.52$ & $2.63 \pm 0.21$ & $3.38 \pm 0.71$ & $3.06 \pm 0.33$ \\
\hline EtOH+DMSO & $3.85 \pm 0.51$ & $4.37 \pm 0.48$ & $3.85 \pm 0.46$ & $3.14 \pm 0.17$ & $2.91 \pm 0.32$ \\
\hline I & $3.28 \pm 0.59$ & $3.47 \pm 0.61$ & $3.25 \pm 0.43$ & $3.20 \pm 0.07$ & $3.24 \pm 0.43$ \\
\hline II & $3.31 \pm 0.33$ & $3.75 \pm 0.22$ & $5.18 \pm 1.14$ & $3.47 \pm 0.44$ & $4.30 \pm 0.60$ \\
\hline III & $3,46 \pm 0,57$ & $2,95 \pm 0,39$ & $2,95 \pm 0,17$ & $4,70 \pm 0,39$ & $2,66 \pm 0,14$ \\
\hline IV & $3.03 \pm 0.43$ & $4.04 \pm 0.65$ & $3.16 \pm 0.45$ & $3.05 \pm 0.19$ & $2.67 \pm 0.36$ \\
\hline V & $6.02 \pm 0.48$ & $8.37 \pm 1.38$ & $6.27 \pm 0,29$ & $6.03 \pm 0,58$ & $5.90 \pm 0.66$ \\
\hline VI & {$[12.73 \pm 0.83]$} & {$[13.20 \pm 1.05]$} & {$[11.06 \pm 1.25]$} & {$[15.47 \pm 2.16]$} & - \\
\hline & $3.25 \pm 0.37$ & $2.34 \pm 0.16$ & {$[4.04 \pm 0.81]$} & {$[8.83 \pm 1.02]$} & $3.79 \pm 0.68$ \\
\hline
\end{tabular}

\# in brackets - zones of partial inhibition of the bacterial growth (bacteriostatic effect). 
A. V. Lozynskyi, H. O. Derkach, V. V. Zasidko et al.

Table 4. The synergistic interaction of thiazolopyridine derivatives with amoxicillin against MRSH, zone of growth inhibition (mm), $\mathrm{M} \pm \mathrm{S}(\sigma), \mathrm{MIC}$ amoxicillin $4000 \mu \mathrm{g} / \mathrm{mL}$.

\begin{tabular}{|c|c|c|c|c|c|}
\hline \multirow{2}{*}{ Compounds } & \multirow{2}{*}{$\begin{array}{c}\text { Control (medium } \\
\text { without amoxicillin) }\end{array}$} & \multicolumn{4}{|c|}{ Media with amoxicillin } \\
\hline & & 1/8 MIC $(500 \mu \mathrm{g} / \mathrm{mL})$ & 1/250 MIC (16 $\mu \mathrm{g} / \mathrm{mL})$ & $1 / 500 \mathrm{MIC}(8 \mu \mathrm{g} / \mathrm{mL})$ & $1 / 1000 \mathrm{MIC}(4 \mu \mathrm{g} / \mathrm{mL})$ \\
\hline $\mathrm{EtOH}+\mathrm{DMSO}$ & $2.83 \pm 0.57$ & $2.94 \pm 0.27$ & $4.22 \pm 0.07$ & $4.99 \pm 0.44$ & $3.91 \pm 0.36$ \\
\hline $\mathrm{I}$ & $2.92 \pm 0.12$ & $2.85 \pm 0.44$ & $2.69 \pm 0.49$ & $5.29 \pm 0.59$ & $3.08 \pm 0.19$ \\
\hline II & $4.11 \pm 0.27$ & $3.42 \pm 0.31$ & {$[11.31 \pm 0.24]$} & {$[11.03 \pm 0.29]$} & $3.35 \pm 0.53$ \\
\hline III & $4.78 \pm 1.01$ & $5.55 \pm 0.56$ & $5.98 \pm 0.64$ & $4.14 \pm 0,61$ & $5.05 \pm 1.03$ \\
\hline IV & $2.92 \pm 0.25$ & $3.25 \pm 0.47$ & $3.17 \pm 0.32$ & $3.97 \pm 0.87$ & $3.15 \pm 0.11$ \\
\hline $\mathrm{V}$ & $3.28 \pm 0.56$ & $3.75 \pm 0.40$ & $4.77 \pm 0.44$ & $6.29 \pm 0.31$ & $8.51 \pm 2.55$ \\
\hline VI & $\begin{array}{c}7.34 \pm 0.36 \\
{[13.66 \pm 0.72]}\end{array}$ & $\begin{array}{c}14.28 \pm 0.53 \\
-\end{array}$ & $\begin{array}{c}13.69 \pm 0.57 \\
- \\
\end{array}$ & $\begin{array}{c}- \\
{[13.53 \pm 0.77]}\end{array}$ & $\begin{array}{c}- \\
{[13.07 \pm 0.32]}\end{array}$ \\
\hline VII & $3.52 \pm 0.65$ & $3.18 \pm 0.11$ & $4.44 \pm 0.68$ & $2.83 \pm 0.43$ & $7.51 \pm 1.32$ \\
\hline
\end{tabular}

\# in brackets - zones of partial inhibition of the bacterial growth (bacteriostatic effect).

Table 5. The synergistic interaction of thiazolopyridine derivatives $(50 \mu \mathrm{g} / \mathrm{mL})$ with amoxicillin against $\beta$-lactamase producing bacteria.

\begin{tabular}{l|c|c|c|c}
\hline \multirow{2}{*}{ Compounds } & \multicolumn{2}{|c}{ Klebsiella pneumonie ATCC 700603 } & \multicolumn{2}{c}{ Staphylococcus haemolyticus ${ }^{*}$ MRSH } \\
\cline { 2 - 5 } & Amoxicillin MIC & Fold reductions & Amoxicillin MIC & Fold reductions \\
\hline Amoxicillin & 256 & & 4096 & 64 \\
\hline+ Clavulanate & 8 & 32 & 4096 & 1 \\
\hline+ I & 256 & 1 & 1024 & 4 \\
\hline+ II & 256 & 1 & 2048 & 2 \\
\hline+ III & 256 & 1 & 4096 & 1 \\
\hline+ IV & 256 & 1 & 2048 & 128 \\
\hline+ V & 256 & 8 & 4096 & 32 \\
\hline+ VI & 32 & 1 & 1 \\
\hline VII & 256 & 128 & 1 \\
\hline
\end{tabular}

\# clinical isolate with both atypical penicillin-binding protein PBP2* and $\beta$-lactamase activities

bryonic kidney cells). We found that $\mathrm{HaCaT}$ and HEK293 demonstrated resistance to the thiazolopyridine derivatives treatment and did not reach the $\mathrm{IC}_{50}$ value at $28.73-41.63 \mu \mathrm{g} / \mathrm{mL}$ (Figure 3). Compound I at $36.88 \mu \mathrm{g} / \mathrm{mL}$ inhibited the growth of HaCaT cells by $30.2 \%$, HEK293 cells - by $42.8 \%$. Compound IV at $30.67 \mu \mathrm{g} / \mathrm{mL}$ inhibited the growth of $\mathrm{HaCaT}$ cells by $24.1 \%$, HEK 293 cells - by $33.0 \%$. Compound $\mathbf{V}$ at $28.73 \mu \mathrm{g} / \mathrm{mL}$ reduced the viability of HaCaT cells by $14.3 \%$, of HEK 293 cells - by $31.3 \%$. Compound VI reduced the viability of HaCaT cells by $7.0 \%$, of HEK 293 cells - by $15.8 \%$. Under compound VII treatment at $41.63 \mu \mathrm{g} / \mathrm{mL}$, we found $26.3 \%$ of $\mathrm{HaCaT}$ cells growth inhibition, and $26.5 \%$ of HEK293 cells growth inhibition (Figure 3).

\section{Conclusions}

The various subtypes of thiazolopyridines IVII were evaluated for in vitro antibacterial activity against Staphylococcus aureus, 

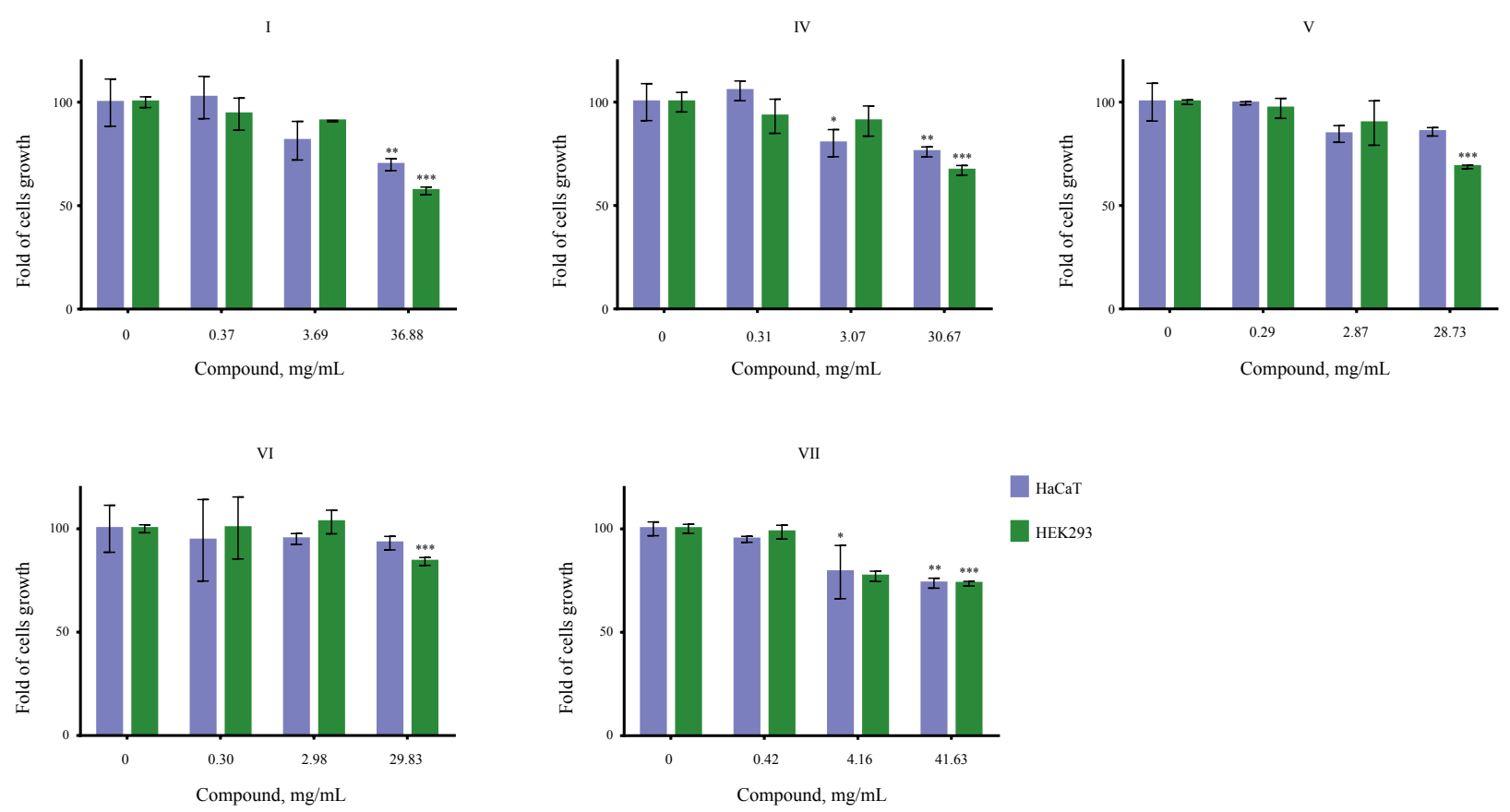

Fig. 3. Cytotoxic action of thiazolopyridine derivatives I-VII towards HaCaT human keratinocytes and HEK293 human embryonic kidney cells. The effect was measured by the MTT assay after $72 \mathrm{~h}$ of cells exposure. Data are presented as the mean $\pm \mathrm{SD} .{ }^{*}-\mathrm{P}<0.05 ; * *-\mathrm{P}<0.01 ; * * *-\mathrm{P}<0.001$ compared with control (non-treated) cells.

Bacillus subtilis and Escherichia coli as well as for antifungal activity against Candida albicans using the agar diffusion and microbroth dilution methods. The antimicrobial screening led to the identification of the active compound $\mathbf{V}$ with the highest activity against Candida albicans $(\mathrm{MIC}=12.5 \mu \mathrm{g} / \mathrm{mL}$ ). The synergism of action with amoxicillin allowed the distinguishing of the most active compound VI with good antimicrobial activity against ES $\beta \mathrm{L}+K$. pneumonie and Staphylococcus haemolyticus (MRSH) strains. Compounds I, IV-VII in concentrations of $0-41.63 \mu \mathrm{g} / \mathrm{mL}$ demonstrated low cytotoxicity against $\mathrm{HaCaT}$ human keratinocytes and HEK293 human embryonic kidney cell lines. Considering the above, the thiazolopyridine derivatives are justified as a fruitful template for the development of a new class of chemotherapeutic agents in the modern drug discovery.

\section{Funding}

The research was funded by the UkrainianChinese program and Ministry of Education and Science of Ukraine, the project M/922019, and the National Research Foundation of Ukraine, the project 2020.02/0035.

\section{REFERENCES}

1. Gomtsyan A. Heterocycles in drugs and drug discovery. Chem Heterocycl Compd. 2012; 48(1):7-10.

2. Baumann M, Baxendale IR, Ley $S V$. The flow synthesis of heterocycles for natural product and me- 
dicinal chemistry applications. Mol Divers. 2011; 15(3):613-630.

3. Dilek Altıntop M, Cantürk Z, Baysal M, Asım Kaplancıkl, Z. Synthesis and evaluation of new thiazole derivatives as potential antimicrobial agents. Lett Drug Des Discov. 2016; 13(9):903-911.

4. Grant EB, Guiadeen D, Baum EZ, Foleno BD, Jin H, Montenegro DA, Nelson EA, Bush K, Hlasta $D J$. The synthesis and SAR of rhodanines as novel class C $\beta$-lactamase inhibitors. Bioorg Med Chem Lett. 2000; 10(19):2179-2182.

5. Carlson EE, May JF, Kiessling LL. Chemical probes of UDP-galactopyranose mutase. Chem Biol. 2006; 13(8):825-837.

6. Suree N, Yi SW, Thieu W, Marohn M, Damoiseaux R, Chan A, Jung ME, Clubb RT. Discovery and structure-activity relationship analysis of Staphylococcus aureus sortase A inhibitors. Bioorg Med Chem Lett. 2009; 17(20):7174-7185.

7. Howard MH, Cenizal T, Gutteridge S, Hanna WS, Tao Y, Totrov M, Wittenbach VA, Zheng YJ. A novel class of inhibitors of peptide deformylase discovered through high-throughput screening and virtual ligand screening. J Med Chem. 2004; 47(27):66696672.

8. Sim MM, Ng SB, Buss AD, Crasta SC, Goh KL, Lee $S K$. Benzylidene rhodanines as novel inhibitors of UDP-N-acetylmuramate/L-alanine ligase. Bioorg Med Chem Lett. 2002; 12(4):697-699.

9. Zidar N, Tomašić T, Šink R, Rupnik V, Kovac A, Turk S, Patin D, Blanot D, Contreras Martel C, Dessen A, Müller Premru M, Zega A, Gobec S, Mašič LP, Kikelj D. Discovery of novel 5-benzylidenerhodanine and 5-benzylidenethiazolidine-2,4dione inhibitors of MurD ligase. J Med Chem. 2010; 53(18):6584-6594.

10. Kaminskyy D, Kryshchyshyn A, Lesyk R. Recent developments with rhodanine as a scaffold for drug discovery. Expert Opin Drug Discov. 2017; 12(12):1233-1252.

11. Abu-Hashem AA, Abu-Zied KM, AbdelSalam Zaki ME, El-Shehry MF, Awad HM, Khedr MA. Design, synthesis, and anticancer potential of the enzyme (PARP-1) inhibitor with computational studies of new triazole, thiazolidinone,-thieno[2,3- $d]$ pyrimidinones. Lett Drug Des Discov. 2020; 17(6):799-817.

12. Holota S, Kryshchyshyn A, Derkach H, Trufin Y, Demchuk I, Gzella A, Grellier P, Lesyk R. Synthesis of 5-enamine-4-thiazolidinone derivatives with trypanocidal and anticancer activity. Bioorg Chem. 2019; 86:126-36.

13. Scarim CB, Jornada DH, Machado MG, Ferreira CM, dos Santos JL, Chung MC. Thiazole, thio and semicarbazone derivatives against tropical infective diseases: Chagas disease, human African trypanosomiasis (HAT), leishmaniasis, and malaria. Eur J Med Chem. 2019; 162:378-95.

14. Ilkiv II, Lesyk RB, Sklyarov OY. The influence of novel 4-thiazolidinone derivative es in cytoprotective mechanisms of small intestine under NSAIDinduced damage. Ukr Biochem J. 2016: 88:99-104.

15. Sklyarova Y, Fomenko I, Lozynska I, Lozynskyi A, Lesyk $R$, Sklyarov A. Hydrogen sulfide releasing 2-mercaptoacrylic acid-based derivative possesses cytoprotective activity in a small intestine of rats with medication-induced enteropathy. Sci Pharm. 2017; 85(4):35.

16. Lozynskyi A, Zasidko V, Atamanyuk D, Kaminskyy D, Derkach H, Karpenko O, Ogurtsov V, Kutsyk R, Lesyk $R$. Synthesis, antioxidant and antimicrobial activities of novel thiopyrano[2,3- $d$ ] thiazoles based on aroylacrylic acids. Mol Divers. 2017; 21(2):427-436.

17. Güzeldemirci NU, Küçükbasmacı Ö. Synthesis and antimicrobial activity evaluation of new 1,2,4-triazoles and 1,3,4-thiadiazoles bearing imidazo[2,1-b] thiazole moiety. Eur J Med Chem. 2010; 45:63-68.

18. Ur F, Cesur N, Birteksoez S, Oetuek G. Synthesis of some new 6-methylimid azo[2,1- $b]$ thiazole-5-carbohydrazide derivatives and their antimicrobial activities. Arzneimittelforsch. 2004; 54(02):125-129.

19. Bekhit AA, Fahmy HT, Rostom SA, Baraka AM. Design and synthesis of some substituted $1 H$-pyrazolyl-thiazolo[4,5- $d$ ]pyrimidines as anti-inflammatory-antimicrobial agents. Eur J Med Chem. 2003; 38:27-36.

20. Gali R, Banothu J, Porika M, Velpula R, Hnamte S, Bavantula R, Abbagani S, Busi S. Indolylmethylene benzo[ $h]$ thiazolo[2,3-b]quinazolinones: Synthesis, characterization and evaluation of anticancer and 
antimicrobial activities. Bioorg Med Chem Lett. 2014; 24(17):4239-4242.

21. Lin R, Johnson SG, Connolly PJ, Wetter SK, Binnun E, Hughes TV, Murray WV, Pandey NB, Moreno-Mazza SJ, Adams M, Fuentes-Pesquera AR. Synthesis and evaluation of 2,7-diaminothiazolo $[4,5-d]$ pyrimidine analogues as anti-tumor epidermal growth factor receptor (EGFR) tyrosine kinase inhibitors. Bioorg Med Chem Lett. 2009; 19(8):2333-2337.

22. Walczyński K, Zuiderveld OP, Timmerman H. Nonimidazole histamine $\mathrm{H}_{3}$ ligands. Part III. New 4-npropylpiperazines as non-imidazole histamine $\mathrm{H}_{3}$ antagonists. Eur J Med Chem. 2005; 40:15-23.

23. Kulkarni SS, Newman AH. Discovery of heterobicyclic templates for novel metabotropic glutamate receptor subtype 5 antagonists. Bioorg Med Chem Lett. 2007; 17(11):2987-2991.

24. Lee YR, Kim DJ, Mook-Jung I, Yoo KH. Synthesis of thia(oxa)zolopyridines and their inhibitory activities for $\beta$-amyloid fibrillization. Bull Korean Chem Soc. 2008; 29(12):2331-2336.

25. Bebernitz GR, Beaulieu V, Dale BA, Deacon R, Duttaroy A, Gao J, Grondine MS, Gupta RC, Kakmak M, Kavana M, Kirman LC, Liang J, Maniara WM, Munshi S, Nadkarni SS, Schuster HF, Stams T, Denny ISt, Taslimi PM, Vash B, Caplan SL. Investigation of functionally liver selective glucokinase activators for the treatment of type 2 diabetes. J Med Chem. 2009; 52(19):6142-6152.

26. Singh B, Bacon ER, Lesher GY, Robinson S, Pennock PO, Bode DC, Pagani ED, Bentley RG, Connell MJ, Hamel LT, Silver PJ. Novel and potent adenosine 3',5'-cyclic phosphatephosphodiesterase III inhibitors: thiazolo[4,5-b][1,6]naphthyridin2-ones. J Med Chem. 1995; 38(14):2546-2550.

27. Lozynskyi A, Zimenkovsky B, Ivasechko I, Senkiv J, Gzella A, Karpenko O, Stoika R, Lesyk R. Synthesis and cytotoxicity of new 2-oxo-7-phenyl-2,3dihydrothiazolo[4,5-b]pyridine-5-carboxylic acid amides. Phosphorus Sulfur Silicon Relat Elem. 2019; 194(12):1149-1157.

28. Lozynskyi A, Zimenkovsky B, Radko L, StypulaTrebas $S$, Roman $O$, Gzella AK, Lesyk R. Synthesis and cytotoxicity of new thiazolo[4,5- $b]$ pyridine-
2(3H)-one derivatives based on $\alpha, \beta$-unsaturated ketones and $\alpha$-ketoacids. Chem Pap. 2018; 72(3):669-681.

29. Matuschek E, Brown DF, Kahlmeter G. Development of the EUCAST disk diffusion antimicrobial susceptibility testing method and its implementation in routine microbiology laboratories. Clin Microbiol Infect. 2014; 20(4):O255-O266.

30. Magiorakos AP, Srinivasan A, Carey RB, Carmeli Y, Falagas ME, Giske CG, Harbarth S, Hindler JF, Kahlmeter G, Olsson-Liljequist B, Paterson DL, Rice LB, Stelling J, Struelens MJ, Vatopoulos A, Weber JT, Monnet DL. Multidrug-resistant, extensively drug-resistant and pandrug-resistant bacteria: an international expert proposal for interim standard definitions for acquired resistance. Clin Microbiol Infect. 2012; 18(3):268-281.

31. Thornsberry C, Mcdougal LK. Successful use of broth microdilution in susceptibility tests for methicillin-resistant (heteroresistant) staphylococci. J Clin Microbiol. 1983; 18(5):1084-1091.

32. Holota SM, Derkach GO, Zasidko VV, Trokhymchuk VV, Furdychko LO, Demchuk IL, Semenciv GM, Soronovych II, Kutsyk RV, Lesyk RB. Antimicrobial activity of some 5-aminomethylene2-thioxo-4-thiazolidinones. Biopolym Cell 2019; 35(5):371-380.

33. Balouiri M, Sadiki M, Ibnsouda SK. Methods for in vitro evaluating antimicrobial activity: A review. $J$ Pharm Anal. 2016; 6(2):71-79.

34. Kim E, Lee SH, Lee SJ, Kwon OP, Yoon H. New antibacterial-core structures based on styryl quinolinium. Food Sci Biotechnol. 2017; 26(2):521-529.

35. Patel HM, Bhardwaj V, Sharma P, Noolvi MN, Lohan S, Bansal S, Sharma A. Quinoxaline-PABA bipartite hybrid derivatization approach: Design and search for antimicrobial agents. J Mol Struct. 2019; 1184:562-568.

36. Hadda TB, Srivastava S, Das B, Salgado-Zamora $H$, Shaheen U, Bader A, Naseer MM. POM analyses of antimicrobial activity of some 2,3-armed 4,5,6,7-tetrahydro-1-benzothiophenes: Favourable and unfavourable physico-chemical parameters in design of antibacterial and mycolytic agents. Med Chem Res. 2014; 23(2):995-1003. 
37. Hafez HN, Alsalamah SA, El-Gazzar AR. Synthesis of thiophene and $N$-substituted thieno[3,2- $d$ ]pyrimidine derivatives as potent antitumor and antibacterial agents. Acta Pharm. 2017; 67(3):275-292.

38. Reheim MA, Baker SM. Synthesis, characterization and in vitro antimicrobial activity of novel fused pyrazolo[3,4-c]pyridazine, pyrazolo[3,4- $d]$ pyrimidine, thieno[3,2-c]pyrazole and pyrazolo[3', $\left.4^{\prime}: 4,5\right]$ thieno $[2,3-d]$ pyrimidine derivatives. Chem Cent $J$. 2017; 11(1):112.

\section{Антимікробна та цитотоксична активність похідних тіазоло[4,5-b]піридину}

А. В. Лозинський, Г. О. Деркач, В. В. Засідко, Ю. Т. Конечний, Н. С. Фінюк, Ю. Т. Лень, Р. В. Куцик, М. С. Регеда, Р. Б. Лесик

Мета. Здійснити скринінг протимікробної та цитотоксичної активності похідних тіазоло[4,5-b]піридину. Методи. Вивчення антибактеріальної та протигрибкової активностей синтезованих сполук проведено in vitro методом дифузії в агар та мікрометодом серійних розведень в агарі відносно клінічних та музейних штамів грампозитивних, грамнегативних бактерій та дріжджів. Встановлено взаємозв'язок структура-антибактеріальна/протигрибкова активність для досліджуваних сполук. Проведено оцінку цитотоксичності цільових сполук відносно клітинних ліній НаСаТ та НЕК293 (МТTтест). Результати. Найвища антимікробна активність спостерігалася для 2-оксо-7-тіофен-2-іл-2,3дигідротіазоло[4,5-b]піридин-5-карбонової кислоти (сполука V) із значенням мінімальної інгібуючої концентрації (МІК) $12.5 \mu \mathrm{g} / \mathrm{mL}$ відносно Candida albicans. Одночасно для синтезованих сполук досліджувався синергізм взаємодії з амоксициліном відносно мультирезистентних клінічних ізолятів $\mathrm{ES} \mathrm{L}^{+}$Klebsiella pneumonie та Staphylococcus haemolyticus (MRSH). Найкращий синергізм взаємодії з амоксициліном спостерігався для сполуки VI. Кератиноцити людини лінії НаСаТ та клітини ембріональної нирки людини НЕК293 продемонстрували стійкість до дії на них похідних тіазолопіридину із значенням $\mathrm{IC}_{50}$ менше 100 $\mu \mathrm{M}$. Висновки. Досліджувані похідні тіазолопіридину становлять цікаву платформу для подальшої розробки нових хіміотерапевтичних лікарських засобів.
К л юч о в і с л о в а: гетероциклічні сполуки, тіазолідинони, тіазоло[4,5-b]піридини, протимікробна активність, антипроліферативна активність

\section{Антимикробная и цитотоксическая активность производных тиазоло $[4,5-b]$ пиридина}

А. В. Лозинский, Г. О. Деркач, В. В. Засидко, Ю. Т. Конечный, Н. С. Финюк, Ю. Т. Лень, Р. В. Куцык, М. С. Регеда, Р. Б. Лесык

Цель. Осуществить скрининг противомикробной и цитотоксической активности производных тиазоло[4,5- $b]$ пиридина. Методы. Изучение антибактериальной и противогрибковой активности синтезированных соединений проведено in vitro методом диффузии в агар и микрометодом серийных разведений в агаре относительно клинических и музейных штаммов грамположительных, грамотрицательных бактерий и дрожжей. Установлена взаимосвязь структура-антибактериальная/противогрибковая активность для исследуемых соединений. Проведена оценка цитотоксичности целевых соединений относительно клеточных линий НaCaТ и НЕК293 (МТТ-тест). Результаты. Наивысшая антимикробная активность наблюдалась для 2-оксо-7-тиофен-2-ил-2,3-дигидротиазоло[4,5-b]пиридин-5-карбоновой кислоты (соединение V) со значением минимальной ингибирующей концентрации (МИК) $12.5 \mu \mathrm{g} / \mathrm{mL}$ относительно Candida albicans. Одновременно для синтезированных соединений исследовался синергизм взаимодействия с амоксициллином относительно мультирезистентных клинических изолятов $\mathrm{ES} \mathrm{L}^{+}$Klebsiella pneumonie и Staphylococcus haemolyticus (MRSH). Лучший синергизм взаимодействия с амоксициллином наблюдался для соединения VI. Кератиноциты человека линии НаСаТ и клетки эмбриональной почки человека НЕК293 продемонстрировали устойчивость к действию на них производных тиазолопиридина со значением $\mathrm{IC}_{50}$ менее $100 \mu \mathrm{M}$. Выводы. Исследуемые производные тиазолопиридина составляют интересную платформу для дальнейшей разработки новых химиотерапевтических лекарственных средств.

Кл юч е в ы е сл ов а: гетероциклические соединения, тиазолидиноны, тиазоло[4,5-b]пиридины, противомикробная активность, антипролиферативная активность.

Received 20.12.2020 